\title{
ISOLATION AND MOLECULAR CHARACTERIZATION OF MYCOPLASMA SYNOVIAE FROM INFECTED CHICKENS WITH RESPIRATORY SIGNS.
}

\author{
B. H. Ali* \\ A. j. Ali* \\ E.H.Yosif* \\ Assist. Prof \\ Assist. Prof. \\ Assist. Prof. \\ Pathology and Poultry Disease.coll.Vet.University of Baghdad \\ ebtisamjawad73@yahoo.com
}

\section{ABSTRACT}

The aim of this study was to investigate the presence of Mycoplasma synoviae in broiler and layer chickens infected with respiratory signs .A total of 80 samples were collected randomly from layer and broiler chickens with respiratory signs in Baghdad from the period between January to May 2017 from trachea, Lung, Air sac, oviduct, tracheal swabs, conjuctivia swabs, choanal swabs and nasal swabs and cultured in PPLO medium with supplements, then positive culture subjected to DNA extracted and Polymerase Chain Reaction assay (PCR) to detect Mycoplasma as a genus and Mycoplasma spp by using specific primers targeting16S rRNA gene. The results of culture revealed that the total rate of Mycoplasma isolates was19/80(23.75\%). DNA was extracted from 19 positive isolates, all nineteen isolates were positive for Mycoplasma genus by conventional PCR assay, and a product of 270 bp was generated by amplification of 16SrRNA gene, while a 210 bp region of $16 \mathrm{~S}$ rRNA gene was amplified for the Mycoplasma synoviae in 19 isolates. The products of amplification of Mycoplasma synoviae16SrRNA gene was sent to MACROGEM (Korea) for sequencing, then submitted in Gene bank database and have accession number:ID: MG846121.1. Sequencing alignment showed that local MS isolates had highly identical with standard references at gene bank, analysis the phylogenetic tree revealed the presence of $100 \%$ identity of the Iraqi isolate to USA: West Virginia, United Kingdom, Australia and Brazil, also had $99 \%$ identity to South Africa ,China, Sweden, USA and VitNamHatey. These result was concluded that circulation of the Mycoplasma synoviae among birds of the flock and caused respiratory signs in chickens.

Keywords:Molicutes,salpengitis,hens,respiratorysign,MS,primers

علي وآخرون

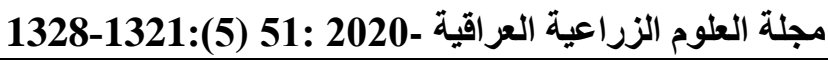

عزل وتوصيف جزيئي :Mycoplasma synoviae من دجاج مصاب بعلامات تنفسية

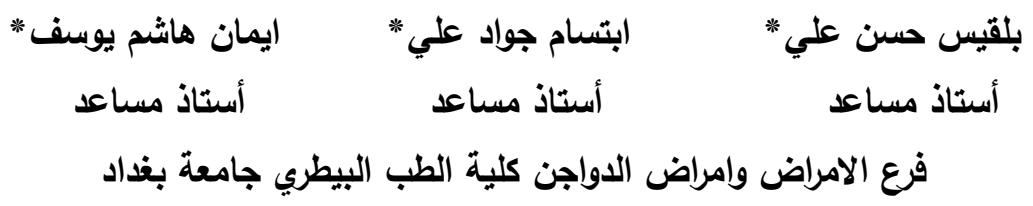

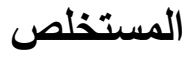

الهلف من هذه الدراسة التحري عن وجود Mycoplasma synoviaeفي دجاج لاحم والبياض المصاب باعراض تنفسيةحيث تم جمع 80عينة بصورة

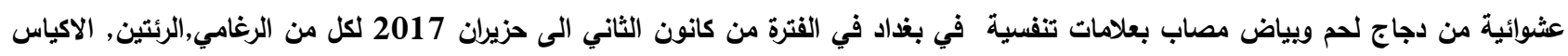

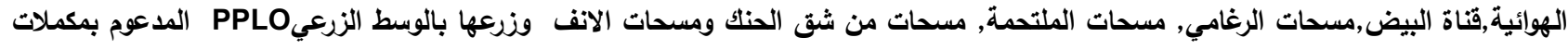

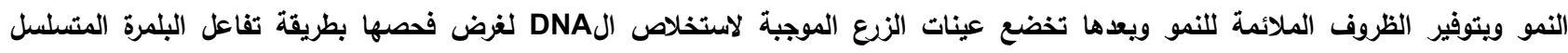

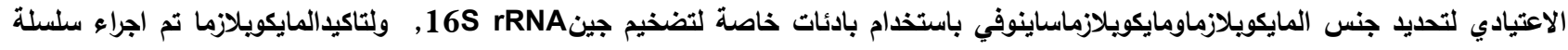

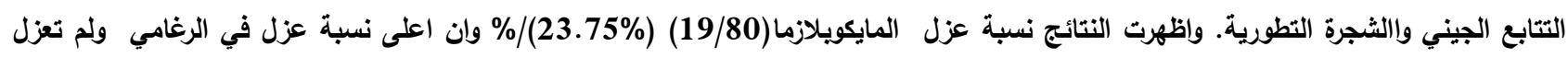

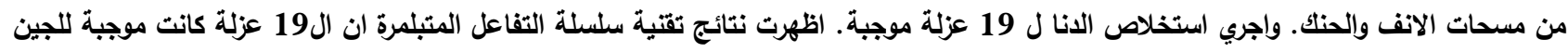
16S rRNA270,

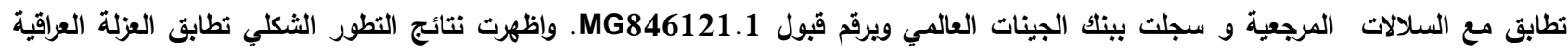

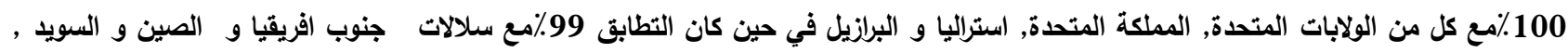

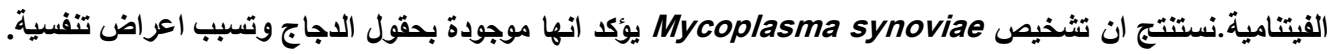

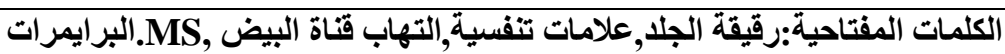




\section{INTRODUCTION}

Mycoplasma synoviae(MS) is one of the important Mycoplasma species that infect avian species, has been listed as a notifiable Mycoplasma by World Organization for Animal Health(28). MS infection causing symptoms like sinusitis, airsacculitis,synovitis,eggshellapexabnormaliti es and result in reduction in egg production and meat quality,causingeconomic losses in the poultry industry worldwide (16).MS cause subclinical upper respiratory tract infection and infectious synovitis in turkey(29) It may cause air sac lesions when combined with Newcastle disease (ND), infectious bronchitis (IB), or both(42). The clinical signs of MS infection could not be differentiated easily from those caused by other avian pathogens, such as avian reovirus, Mycoplasma gallisepticum (MG), Staphylococcus aureus, Escherichia coli, Pasteurella multocida, and "Salmonella spp., which in poultry species could cause symptoms similar to MS infection (17).Transmission of MS is accomplished laterally via direct contact and respiratory aerosols, and vertically within eggs(27). Like other pathogenic Mycoplasmas MS growth and persist in the host $(24 ; 11 ; 1)$ The morbidity of about $5-15 \%$ in chicken and $1-20 \%$ in turkey has been associated directly with MS infection alone and indirectly by co-infection with other pathogens $(32 ; 17)$. The methods recommended by "OIE "for MS dignosis are isolation (culture), serological assays and polymerase chain reaction (PCR) $(26 ; 2 ; 6)$. DNA sequence analysis of the" 16S rRNA gene" has proven to be useful for Mycoplasma identification and in phylogenetic studies(40). The molecular characterization of MS strains may assist in epidemiological studies to determine the source of infections and relationships among strains isolated from neighbouring or related flocks Kursa $(18 ; 15)$ Because of the above causes and possibility of contributing of MS in distributing the respiratory disease in Iraq the current study is designed to detect the presence of MS in the broiler and layer chickens infected with respiratory signs and study the molecular characterization ,sequencing , phylogenetic tree of in Iraq.

\section{MATERIALS AND METHODS}

For isolating Mycoplasma synoviae different samples were collected during the period of 3 months .A total of 80 samples (organs and swabs) including trachea,lung,air sac, oviduct, tracheal swabs ,conjuctivia swabs,air sac swabs and choanal cleft swabs taken from layer and broiler poultry flocks in Baghdad were suffering from respiratory signs. were collected at necrobsy,samples were transported to the laboratory labore in refrigerated container(25,27) and culture in PPLO broth and PPLO agar which was prepared by using 6.37 gand $8.87 \mathrm{gm}$ respectively $1250 \mathrm{ml}$ distal water then added sterile supplementary growth(horse serum $10 \%$,yeast extract $10 \%$ and ampicillin 500 or $1000 \mathrm{mg}$ )and inhibitory solutions(thalium acetate $1 \%$ )were added under restricted sterile environment(27).Small pieces of organ or swab were placed in 1-2 ml of PPLO broth with supplement growth and incubated aerobicaly at 37 for three days and then streaked on PPLO agar in an inverted position in candle jar at 37 increased humidity and $\mathrm{CO} 2$ tensition for 6 days.All plates were examined for Mycoplasma growth at 3days intervals under dissecting microscope (43) DNA extraction was performed on positive Mycoplasma colony suspected, that grow on pplo agar were sub culture overnight in pplo broth and used for DNA extraction according to(21) DNA was extracted according to manufacture of DNEasy blood and tissue extraction kit (QIAGEN, USA)conventional PCR assay was used in this study for detection of Mycoplasma.The positive samples of Mycoplasma genus subjected to PCR for detection of Mycoplasma synoviae so for detection of Mycoplasma genus by using primers based 16Sribosomal RNA gene were designed by Botes et al. (5) primers based $16 \mathrm{~S}$ ribosomal RNA gene were designed by(27) for detection of Mycoplasma synoviae, amplificationMycoplasma synoviae strain obtained from conventional PCR was sent by Macrogen company to Korea. (NICEM) company for sequencing (sanger method), Nucleotides sets were used to obtain the identity score of our isolate strain with the other world references strains by the Mega6+NCBI program according to(39) . 


\section{RESULTS AND DISCUSSION}

In the present study, a total of 80 samples were collected randomly from layer and broiler chickens with respiratory signs (10) from trachea, (10) Lungs, (10) Air sacs, (10) oviducts, (10) tracheal swabs, (10) conjunctiva swabs, (10) choanal swabs and (10) nasal swabs . percentage of positive samples revealed by culture was $23.75 \%$ as show in table (1), positive samples revealed growing typical fried egg colonies figure(1).Isolation by culture was the gold-standard method for MS detection(8) isolation may also be compromised by rivalry from other pathogens" especially in the cases of chronically infected animals" which in general have relatively low MS loads (33). In the present study the isolation of Mycplasma was done by PPLO broth and agar medium with supplements which was found suitable for isolation of Mycoplasma with characteristic morphology obtained on PPLO agar was small, smooth, circular, having fried egg appearance with central dense and outer translucent area, similar characteristics of colonies of Mycoplasma spp. have been reported by several studies $(16 ; 19)$ the result showed the highest occurrence of Mycoplasma spp. were in the tracheal 5/10(6.25\%) following by air sac swabs 4/10(5\%), tracheal swabs and oviduct $3 / 10$ ( $3.8 \%)$, Conjunctival swabs and lung $2 / 10(2.5 \%)$ these result was similar to other studies by (12) ; Rauf et al.( 32) and Gondal et al.(13) whom found that the highest number of samples collected from trachea of birds were positive for Mycoplasma through culture technique ,there was no isolate from the choanal and nasal swabs this may be due to using of dry swabs reducing the viability of microorganisms (44) while the result of Mycoplasma isolation from oviduct in this study was similar to the result that obtained by Mansour(24) and Serag (40) whom isolated Mycoplasma from chicken's respiratory and reproductive systems this related to the air sacs and surface of the ovaries "which are in close proximity to the abdominal air sacs", as well as the mucosal surface of the oviduct (35)or that Mycoplasma organism can spread from the respiratory tract via blood stream to the ovaries causing pathological conditions and that indicated the tissue proclivity of
Mycoplasma (29). Nineteen positive Mycoplasma samples were tested by conventional PCR technique with primers a" $270 \mathrm{bp}$ region of $16 \mathrm{~S}$ rRNA gene" was amplified for the Mycoplasma genus the result show all isolates were scored to be positive Mycoplasma spp. fig. (2).While a $210 \mathrm{bp}$ region of $16 \mathrm{~S}$ rRNA gene was amplified for the Mycoplasma synoviae also all isolates positive to MS as shown in fig. (3). The results of the $16 \mathrm{Sr}$ RNA gene revealed that MS primers of the $16 \mathrm{~S}$ rRNA gene had successfully targeted the respective gene and shown the single bands of the $16 \mathrm{~S}$ RNA gene of MS at $1500 \mathrm{bp}$ in the isolate of MS as showed in figure (4) It was stated that a combination of culture and PCR is the most recommended method because of Mycoplasma are having very small genome size, they fail to show the many biochemical pathways as compared to bacteria to identify at species level $(7 ; 43)$ These results are in line with results obtained by Bagheri et al.(3); Zahraaet al.(45); 14 ; 38) whom reported that 16SrRNA gene was able to identify all the examined avian Mycoplasma and routine PCR test in conjunction with conventional identification methods could be effective in providing a more accurate profile of the prevalence of Mycoplasma in poultry flocks. Although several researchers have described the use of conventional PCR in detection Mycoplasma directly from clinical samples such as nasal swab, trachea and air sac $(30 ; 4 ; 32 ; 41)$.Due to lack of differentiation in colony characteristics of different Mycoplasma species, PCR could easily pick up M.synoviae through targeting specific primers for diagnosis of MS by PCR amplification of the 16S rRNA gene using MS specific primers $(26 ; 31 ; 36)$ the increase in MS happen might be due to two causes; the subclinical form known in most MS infection cases as well as the implemented control strategies ,many national control programs focus on $\mathrm{MG}$ "as more clinically relevant avian Mycoplasma" with less strict strategies towards MS control(20). The high prevalence of MS infection in present study was agreement with $(9 ; 10 ; 37)$.whom recorded in above 60 weeks of age .Sequencing of 16SrRNA gene of Mycoplasma synoviaewas performed to isolates, the nucleotide sequence 
of chicken Mycoplasma synoviae 16SrRNA gene were submitted in gene bank database and have accession number: ID, the phylogenic of one Iraqi field isolate of MS that was deposited in NCBI under the accession number MG846121.1. Based on the nucleotide phylogenetic tree of 16Sribosomal RNA gene found that MG846121.1Iraqi isolate was 100\% similar to USA: West Virginia CP011096.1, United Kingdom: LS991953.1, Australia: CP021129.1 and BrazilAE017245.1, also had $99 \%$ similar to South Africa MH539137.1, China MF319540.1, Sweden U04645.1 , USA NR_044811.1 and VitNamHatey : AM073015.1 figure (5).The phylogenic analysis of one Iraqi field isolate that was deposited in NCBI under the accession number, based on the nucleotide phylogenetic tree of 16Sribosomal RNA gene we found that Iraqi isolate was $100 \%$ similar to USA: West Virginia, United Kingdom:, Australia: and Brazil, also had $99 \%$ similar to South Africa, China, Sweden, USA and VitNamHatey isolate indicating the geographical distribution of MS strains between countries due to weak biosecurity strategy ,also implicating the epidemio geographical relation-ship between these isolates(23). The current study was consider first report in Iraq that involvement isolation of Mycoplasma synoviae by culturing and confirmation by PCR test.

Table 1. Results of Mycoplasma isolation from specimens by culturing.

\begin{tabular}{|lcl|}
\hline Samples (Organs and swabs) & No. of examined samples & $\begin{array}{c}\text { No. and percentage of } \\
\text { positive samples }\end{array}$ \\
\hline Tracheal & 10 & $\mathbf{5}(6.25 \%)$ \\
Lung & 10 & $\mathbf{2}(2.5 \%)$ \\
Air sac & 10 & $\mathbf{4}(5 \%)$ \\
oviduct & 10 & $\mathbf{3}(3.8 \%)$ \\
Tracheal swabs & 10 & $\mathbf{3}(3.8 \%)$ \\
Choanal cleft swabs & 10 & $\mathbf{0}(0.00 \%)$ \\
Conjunctival swabs & 10 & $\mathbf{2}(2.5 \%)$ \\
Nasal swabs & 10 & $\mathbf{0}(0.00 \%)$ \\
Total count / percentage of isolate & 80 & $(19) /(23.75 \%)$ \\
\hline
\end{tabular}
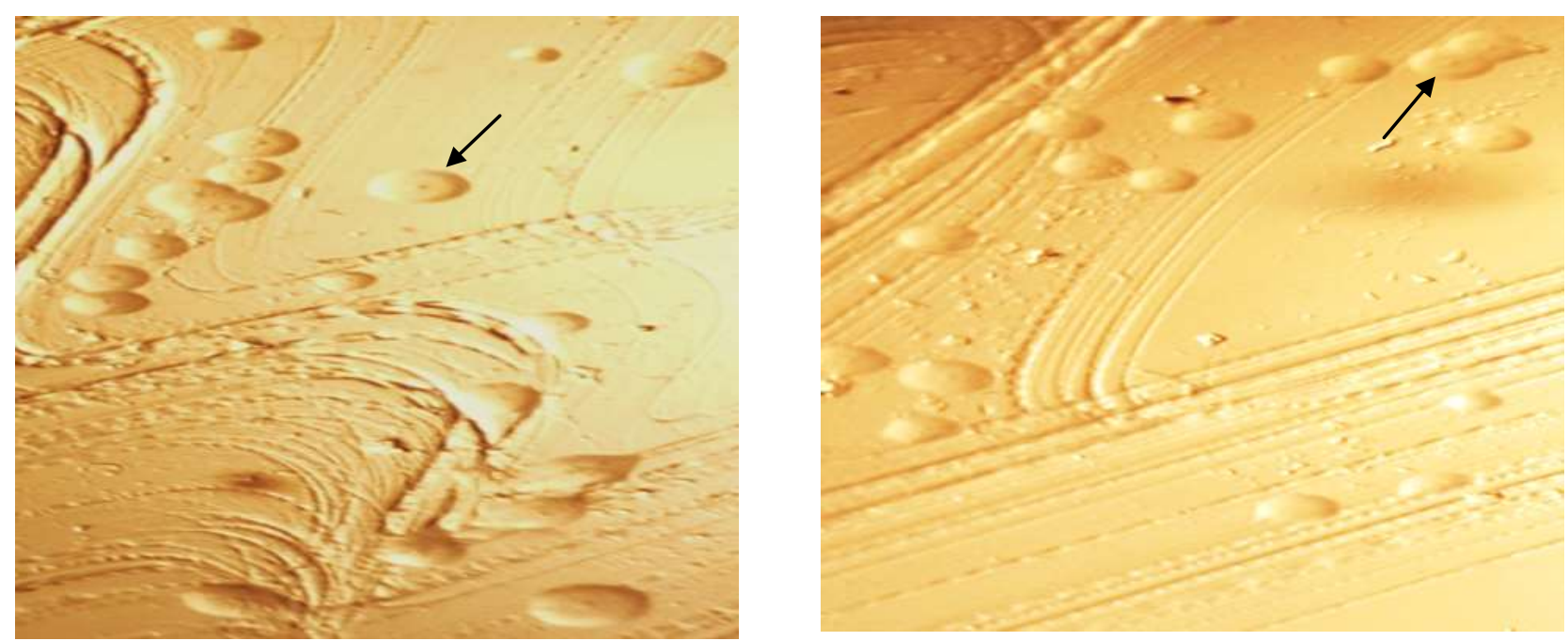

Figure 1.shows fried egg colony of Mycoplasma 


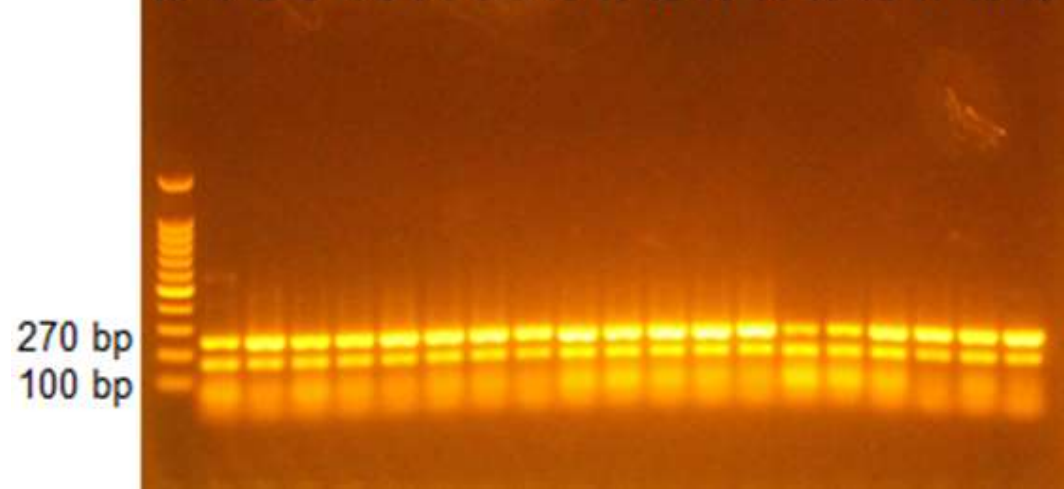

Figure 2. Agarose gel electrophoresis image that show the PCR product analysis of 16S rRNA gene in Mycoplasma genus positive isolates. Where $M$ : marker (1500-100bp), lane (1-19) positive Mycoplasma genus at (270bp) PCR product

\section{M12345678910111213141516171819}

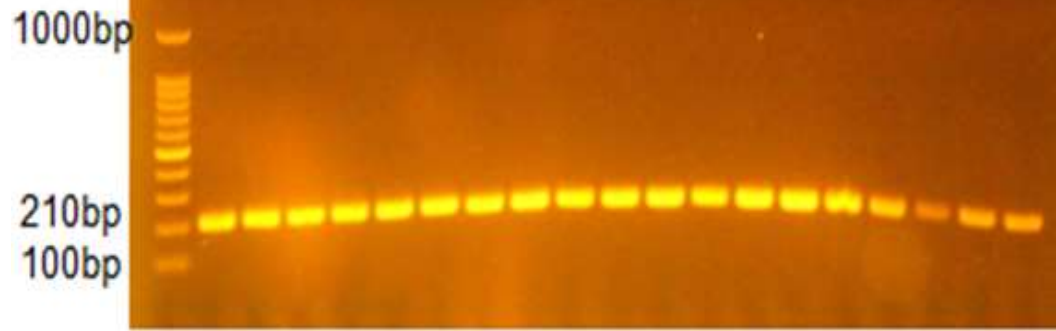

Figure 3.Agarose gel electrophoresis image that show the PCR product analysis of 16S rRNA gene in Mycoplasma synoviae positive isolates. Where M: marker (100-1000bp), lane (1-19) positive Mycoplasma synoviae at (210bp) PCR product

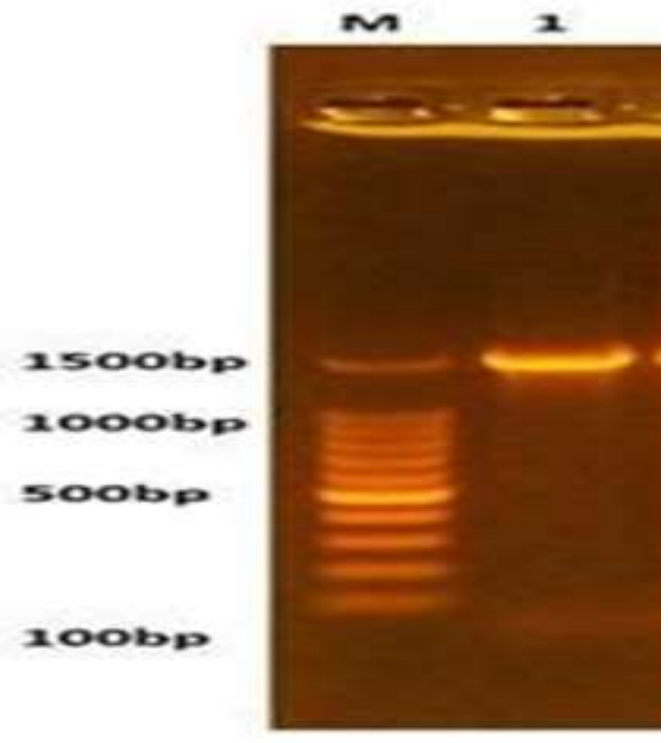

Figure 4.Electrophoresis of amplicon PCR products of field isolates of MS had a single band at size1500bp represent 16sRNA gene,(M: marker (1500bp) 

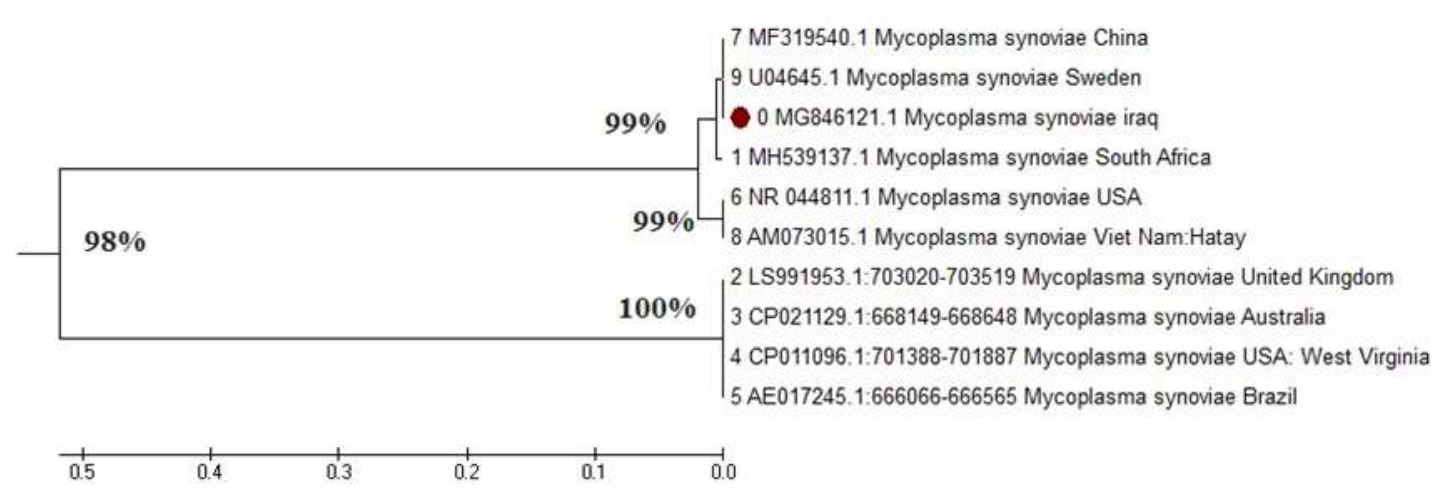

Figure 5.show phylogenic tree of one isolate using Mega6+NCBI

\section{REFERENCES}

1-Ali J.and B. H. Ali 2019. Inflammatory reaction against Mycoplasma gallisepticum infection in broiler .The Iraqi Journal of Agricultural Sciences 50:(5)1432-1438

2-Amer ,M.M; H.M,Mekky Fedawy 2019. Molecular identification of Mycoplasma synoviae from breeder chicken flock showing arthritis in Egypt. HS.Vet .World.;12(4):535541

3-Bagheri, H.; A.Doosti, and A. Arshi, 2011.Detection of Mycoplasma gallisepticum in Chaharmahal VaBakhtiari Province Poultry using PCR. Global Veterinaria, 7(1): 54-59

4-Bibank, F.; G.A.Kalidari,; J.Razmyar, and M. Rad .2013. Isolation of Mycoplasma spp from broiler flocks with respiratory syndrome in Mashhad, Iran. Iranian J Vet. Sci. Tech., 5 (1):11-18

5-Botes ,A; B. ,Peyrot; A. Olivier; W., Burger and D.,Bellstedt.2005.Identification of three novel Mycoplasma species from ostriches in South Africa. Vet Microbiol. ;111:159-69

6-Dijkman, R.;A., Feberwee and W.J.M., Landman .2013. Validation of a previously developed quantitative polymerase chain reaction for the detection and quantification of Mycoplasma synoviae in chicken joint specimens. Avian Pathol., 42: 100-107

7-Faiz M., S.,Khurram Fareed ${ }^{1}$, Urooj Zafar ${ }^{1}$, T. Ahmed Khan and A. Ahmad .2017. Development and Evaluation of Culture Enhanced Tetra-PCR for Differential Diagnosis of Mycoplasma gallisepticum and M. synoviae Pakistan J.Zool.,49(6), 2133-2140 8-Feberwee, A., D. R. Mekkes, J. J. de Wit, E. G. Hartman, and A.Pijpers. 2005. Comparison of culture, PCR, and different serologic tests for detection of Mycoplasma gallisepticum and Mycoplasma synoviae infections. Avian Dis. 49:260-268
9-Feberwee A.and T.S, Landman WJM, 2008. Seroprevalence of Mycoplasma synoviae in Dutch commercial poultry farms, Avian Pathol, 37, 6, 629-33

10-Fraga, A. P., T. de Vargas, N. Ikuta, A. S. Fonseca, A. J. Celmer,E. K. Marques, and V. R. Lunge. 2013. A multiplex real-time PCR for detection of Mycoplasma gallisepticum and Mycoplasma synoviae in clinical samples from Brazilian commercial poultry flocks. Braz. J. Microbiol. 44:505-510

11-Gabriel ,S.C.;H. L. Shivaprasad and R. P. Chin.2005 .Systemic Mycoplasma synoviae infection in broiler chickens .Avian Pathology $34(2), 137 / 142$

12-Gharaibeh S. and R. A. 1. ,Dirgham .2008. The Use of Molecular Techniques in Isolation and Characterization of Mycoplasma gallisepticum from Commercial Chickens in Jordan. International Journal of Poultry Science 7 (1):28-35

13-Gondal,M.;M.,Rabbani;K.,Muhammad;T.,

Yaqub;A. Babar, and Sheikh. 2015. Characterization of Mycoplasma gallisepticum isolated from commercial poultry flocks. J. Anim. Pl. Sci., 25: 108-113

14-Hossam, $\quad$ M.,A.W; $\quad$ E.,Mona;E., Mahmoud;E., Rehab and E. D.T. Salah.2016. The Recovery and Molecular Diagnosis of Mycoplasma gallisepticum Infection in Commercial Poultry Flocks in Egypt.Indian Journal of Science and Technology,9(29).

15-Huang, L., Z. Xie, L. Xie, X. Deng, Z. Xie, S.Luo,J.Huang,T.Zeng, and J. Feng. 2015. A duplex real-time PCR assay for the detection and quantification of avian reovirus and Mycoplasma synoviae. Virol. J. 12:22

16-Kleven S. H. and M., Garcia 2003.Epidemiology of Mycoplasma infections based on analysis of gene polymorphism, FEMS Microbilogy Letters 222 (1):101 
17- Kleven, S. H., and Ferguson-Noel, N. (2008). Mycoplasma synoviae Infections. In: Saif, Y.M., Fadly, Feberwee, A., De Vries, T.S., Landman, W.J.M. A.M., Glisson, J.R., McDougald, L. ., Nolan, L. K., , D.E. (Eds.), Diseases of Poultry. $12^{\text {th }}$ Ed, Blackwell Publishing, Iowa State University Press, USA, Ames, pp.845-856

18-Kursa, O.; A., Pakuła; G., Tomczyk; S., Paśkoand A.,Sawicka 2019. Eggshell apex abnormalities caused by two different Mycoplasma synoviae genotypes and evaluation of eggshell anomalies by full-field optical coherence tomographyBMC Veterinary Research volume 15, Article number: 1 | 4 Citations

19-Ley,D. H. 2008.Mycoplasma gallisepticum infection. In: Diseases of Poultry $12^{\text {th }}$ ed. YM Saif, AM Fadly, JR Glisson, LR McDougald, LK Nolan and DE Swayne (eds) Ames: IABlackwell Publishing Professional .pp:807834

20-Lockaby, S. B.; F. J., Hoerr; L. H., Lauerman;; B. F., Smith;A.M.,Samoylov; M. A., Toivio-Kinnucan, and S. H., Kleven.1999. Factors associated with virulence of Mycoplasma synoviae. Avian Dis43, 251-261

21-Landman, W.J., 2014. Is Mycoplasma synoviae outrunning Mycoplasma gallisepticum A view point from the Netherlands. Avian Pathology .43, 2-8

22-Marois C; J.P.,Picault ; M. K, Kobisch 2005..Experimental evidence of indirect transmission of Mycoplasma synoviae. Vet Res. Sep-Dec;36(5-6):759-69

23-Marcos R. B.; E.,Mettifogo; J.,T imenetsky; S., Kleven and A. J. Piantino Ferreira .2009. Epidemiological survey on Mycoplasma gallisepticum and M. synoviae by multiplex PCR in commercial poultry Pesq. Vet. Bras. vol.29 no.7

24-Mansour, A. F.1995. Studies on the prevalence of avian mycoplasma in Egypt and their economic importance. M. Sc. Thesis. Faculty of Vet. Med., Cairo University.pp:66-70

25-Noormohammadi, A. H. 2007. Role of phenotypic diversity in pathogenesis of avian mycoplasmosis. Avian Pathol. J. 36, 439-444. 26-OIE.2008. Manual of Diagnostic tests and Vaccines for Terrestrial Animals. Chapter 2.3.5: Avian mycoplasmosis
(Mycoplasma gallisepticum, M. synoviae), pp. 482-496

27-OIE. 2015. Avian mycoplasmosis (Mycoplasma gallisepticum, M.synoviae) in Manual of diagnostic tests and vaccines for ter-restrial animals. World Organisation for Animal Health (OIE),Paris, France.pp:480499

28-OIE. 2018. Avian mycoplasmosis (Mycoplasma gallisepticum, M. synoviae) in Manual of diagnostic tests and vaccines for terrestrial animals. World Organisation for Animal H ealth (OIE); Paris, France: 2018 29-Peebles, E. D.; T. K, Parker; S. L., Branton; K. L., Willeford; M. S., Jones; P. D., Gerard; G. T., Pharrand W. R., Maslin. 2004. Effects of an S6 strain of Mycoplasma gallisepticum inoculation before beginning of lay on the leukocytic characteristics of commercial layers. Avian Dis., 48: 196-201 30-Ramadass, A.; R.,Senthilkumar; T. M. A. G, Venkatesh and V., Ramaswamy 2006. Isolation and characterization of Mycoplasma gallisepticum and Mycoplasma synoviae from poultry. Indian Journal of Animal Science. 76: 796-798.

31-Rasool, A., A. A, Anjum, M., Rabbani, M, Lateef, F., Akhter, H., Afroz,, J. , and M., Nawaz. 2018. Molecular characterization and phylogenetic analysis of Mycoplasma synoviae isolated from chicken.J. Anim. Plant Sci., 28(2): 491-497

32-Rauf, M.; Z. I.,Chaudhary; M., Younus; A. A, Anjum; M. A, Ali ;A. N., Ahmad and M.U.R.,Khan.2013. Identification of Mycoplasma gallisepticum by PCR and conventional diagnostics from with leghorn layer flocks. The Journal of Animal and Plant Sciences, 23(2): 393-399

33-Raviv, Z.; D. and H, Ley. 2013. Mycoplasma gallisepticum infection. In: Diseases of Poultry, 13thEd. Swayne DE. editor.Wiley-Blackwell, Ames, Iowa, pp:877893.

34-Roussan, D. A.; G. Khawaldeh, and I. A. Shaheen. 2015. A survey of Mycoplasma gallisepticum and Mycoplasma synovaie with avian influenza H9 subtype in meat-type chicken in Jordan between 2011-2015. Poult. Sci. 94:1499-1503

35- Sadeq S. A. M 2019. Effect of dietary supplementation of Miaclost on perfect of 
dietary supplementation of Miaclost on performance and gut morphology in broiler chickens challenged with Escherichia coli. Iraqi Journal of Agricultural Sciences 50(2):506-515.

36-Schrader, C., A. Schielke, L. Ellerbroek, and R. Johne. 2012. PCR inhibitors occurrence, properties and removal. J. Appl. Micro-biol. 113:1014-1026

37-Seifi,S. and M. R., Shirzad .2012.Incidence and risk factors of Mycoplasma synoviae infection in broiler breeder farms of Iran .Vet. World, 5(5): 265-268.

38- Sumitha, P. and K.,Sukumar. 2017. Incidence of Mycoplasma synoviae induced eggshell apex abnormality in desi chicken. Indian Vet. J., 94(5): 36-37

39-Tamura K, G.; D.,Stecher; A., Peterson ;A., Filipski; S., Kumar MEGA6.2013 Molecular Evolutionary Genetics Analysis version 6.0. Mol .Biol. E.30(12):2725-9

40-Tebyanian H; S. H., Mirhosseiny; B., Kheirkhah; M., Hassanshahian; and H., Farhadian. 2014. Isolation and Identification of Mycoplasma synoviae From Suspected Ostriches by Polymerase Chain Reaction, in Kerman Province, Iran. undishapur J Microbiol. Sep;7(9):e19262
41-Tomar, P.;Y., Singh; N,K.,Mahajan;N., Jindal and M., Singh.2017. Molecular Detection of Avian Mycoplasmas in Poultry Affected with Respiratory Infections in Haryana (India). Int. J. Curr. Microbiol. App. Sci., 6(6): 2155-2162

42- Ulaiwi, A. H. 2019.Role of some aromatic essential oil on immune status against infectious bronchitis vaccine and lipid profile of broiler chicken. Iraqi Journal of Agricultural Science volume:50(6):1630-1634 43-Uphoff, C. C. and H,G., Drexler. 2002. Detection of Mycoplasma in leukemialymphoma cell lines using polymerase chain reaction. Leukemia 16, 289-293

44-Zain, Z.M. and J.M. Bradbury, J.M., 1996. The Optimising conditions for isolation of Mycoplasma gallisepticum collected on applicator swabs. Vet. Microbiol.,. 49: 45-57 45-Zahraa, F.; I., Aini, ;A. R, Omar;Ha-Bejo, M., and C.G., Tan. 2011. Molecular identification of two genetic markers that distinguish between pathogenic and nonpathogenic strains of Mycoplasma gallisepticum. Animals and Veterinary Advances Journal,10, 2846-2855 